\title{
«THE ANTI-SOVIET TROTSKIST ORGANIZATION»: HISTORIOGRAPHICAL NOTES
}

(C) 2016

M.D. Tochiony, candidate of historal sciences, associate professor of the Chair of Humanities and Social Disciplines Ulyanovsk Institute of Civil Aviation named after Chief Marshal of Aviation B.P. Bugaev, Ulyanovsk (Russia)

Abstract. Since 1956, historians, legal scholars and representatives of other social Sciences and Humanities have been trying to understand what happened to the population of our country in the second half of the 30-ies of XX century. Why did people lose common sense and believe in delusional fabrications of I. V. Stalin about the transformation of millions of Soviet citizens who piously believed in the ideals of Marxism-Leninism, into the malignant saboteurs? Why did most of them demand severe punishment of traitors, when the Soviet Newspapers reported the discovery of an enormous conspiracy in the ranks of the Red army?

The article is an attempt to assess the General opinions of the so-called «military» («anti-Soviet Trotskist military organization), which resulted in the shooting of the prominent Soviet military leaders led by M.N. Tukhachevskiy I.P. Uborevich, I.E. Yakir, A.I. Cork and thousands of brave, talented Soviet soldiers, committed to the cause of socialism. Thus the armed forces of our country, its defense was dealt a severe blow, which, in the opinion of some researchers predetermined the huge losses of the Soviet Union, especially in the first years of Hitler's aggression.

We are especially interested in the following aspect of «the military» - was it fabricated, and the «Red Marshal» was its innocent victim, or, on the contrary, was it investigated in complete conformity to the law and the perpetrators got the punishment they deserved?

The author has assessed the key issues - both liberal-minded researchers and apologists of Stalinism.

Keywords: the war, the Soviet Union, repression in the Red army, the Red army, the military case, the court, I.V. Stalin, M.N. Tukhachevsky, F.F. Raskolnikov, crime, traitors, spies, historiography.

УДК 94(47).084.8

\section{ИЗ ИСТОРИИ СТАНОВЛЕНИЯ ТРОЛЛЕЙБУСНОГО СООБЩЕНИЯ В ПЕНЗЕ}

(C) 2016

\section{А.В. Горшенин, ассистент кафедры гуманитарных дисциплин} Медицинский университет «Реавиз», Самара (Россия)

Аннотация. Городской транспорт является неотъемлемой частью городского хозяйства. Без общественного транспорта невозможно представить существование крупных и средних городов с их большими линейными размерами. В данной статье рассматривается история становления троллейбусного транспорта в Пензе в 1940-е гг. Ещё в дореволюционные годы местные власти хотели организовать в Пензе работу трамвая, но все замыслы так и остались на бумаге. После Октябрьской революции и начала индустриализации, городские власти вновь столкнулись с задачей организации стабильного внутригородского транспорта. В середине 1930-х гг. по просьбе рабочих в Пензе было организовано движение узкоколейного внутригородского поезда. Но функционировал он недолго: через 2 года в силу технических сложностей, от него пришлось отказаться. В годы Великой Отечественной войны, в связи с ростом города, вновь встал вопрос об организации стабильной работы транспорта. Было решено строить троллейбусную линию. Источниками статьи послужили документы федеральных и региональных архивов - Государственного архива Российской Федерации, филиала Российского государственного архива научнотехнической документации, Государственного архива Пензенской области и Отдела фондов общественнополитических организаций ГАПО. Дополняют архивный пласт источников материалы местной периодической печати рассматриваемых лет. Прослеживаются такие процессы как проектирование, строительство и первые несколько лет эксплуатации троллейбуса. Затрагиваются проблемы, которые возникали при создании трассы электротранспорта, показана её роль в городском хозяйстве города.

Ключевые слова: региональная история, история повседневности, город, троллейбус, трамвай, городской транспорт, общественный транспорт, коммунальное хозяйство, городское хозяйство, благоустройство, градостроительство, Великая Отечественная война, послевоенный период, Пензенская область, Пенза.

Постановка проблемы в общем виде и ее связь с важными научными и практическими задачами. Общественный транспорт выполняет важную роль в жизни города. При отсутствии транспорта, население, работающее на том или ином предприятии, вынуждено было бы жить только рядом с ним, и город фактически распался на отдельно расположенные населённые пункты. Изучение становления и развития общественного транспорта в региональном аспекте позволяет показать рост значимости городов.

Анализ последних исследований и публикаций, в которых рассматривались аспекты этой проблемы и на которых основывается автор; выделение неразрешенных раньше частей общей проблемы. Изучение про- блематики истории развития городского транспорта условно можно разделить на два периода: советский и постсоветский. Советский период характеризуется слабым изучением проблем развития общественного транспорта. Как правило, история городского транспорта рассматривалась в контексте работ по городскому и коммунальному хозяйству. Здесь стоит отметить работу С.П. Петрова [1] и сборник «Пензенская область за 50 лет советской власти» [2]. В постсоветский период у исследователей появляется интерес к развитию регионального общественного транспорта, в частности пензенского. Необходимо назвать статьи Н.И. Полосина [3] и П.В. Кашаева [4]. 
Формирование иелей статьи (постановка задания). На протяжении первой половины XX в. городское пространство Пензы значительно возросло. В связи с этим, уже в годы войны принимается решение о строительстве троллейбусной ветки. Рассмотрение процессов создания троллейбусной линии даёт возможность проследить укрепление статуса Пензы как областного центра не только формального, но и фактического. Цель работы - проанализировать основные этапы создания городского электрического транспорта.

Изложение основного материала исследования с полнылм обоснованием полученных научных результатов. Развитие городского пассажирского электротранспорта Пензы имеет долгую и весьма непростую историю. Впервые власти задумались о создании трамвая на рубеже XIX-XX вв. Так, в июне 1897 г. был объявлен конкурс «на устройство в Пензе концессионным способом городских железных дорог». В результате конкурса Дума выбирает проект бельгийца Эдуарда Дени, который и утвердили в сентябре 1902 г. Но прошло более двух лет, а Дени в Пензе так и не появился, поэтому в мае 1905 г. городская Дума разорвала с ним договор.

В дальнейшем власти города предприняли еще несколько безрезультатных попыток договориться с предпринимателями об устройстве в Пензе трамвайного сообщения. Только в июне 1911 г. городской Думе удалось решить вопрос о возможности поручить разработку проекта трамвая и электростанции инженеру М.К. Поливанову, который возглавлял трамвайную сеть в Москве. Из городской казны на это было отпущено 3 тыс. руб.

Поливанов направил в Пензу своего помощника инженера А.М. Авенариуса для ознакомления с расположением города и нанесением на план линии трамвая. Уже к середине декабря 1911 г. на стол городского головы лег эскизный проект с пояснительной запиской, а к ним были приложены и запросные листы для фирм, поставлявших необходимое оборудование.

Но реализовать данный проект помешала Первая мировая война, а за ней революционные события 1917 г. Вновь к идее строительства вернулись в 1930-е гг. В ноябре 1930 г. был заключен договор на составление проекта трамвая между Пензенским горисполкомом и Всесоюзным электрическим объединением. Но у города не было средств, а центральная власть не выделяла денег для строительства трамвая в тогда ещё провинциальной Пензе [5, с. 16].

Но разраставшаяся Пенза всё больше нуждалась в стабильном городском транспорте. Поэтому в 1935 г.на городских улицах появился принципиально новый вид пассажирского транспорта. Произошло это благодаря настойчивой просьбе сотрудников велозавода. Рабочие писали жалобы во все инстанции о том, как нелегко по утрам добираться из центра города на окраину, где было расположено предприятие. И из столицы прислали директиву - немедленно пустить до завода «прямой» трамвай. Хотя скорее этот вид транспорта можно определить как городской поезд. Пензенский «трамвай» представлял собой мотовоз с прицепленными к нему несколькими вагонами, курсировавший по узкоколейной железной дороге. Он осуществлял доставку рабочих к велозаводу. Функционировал этот узкоколейный трамвай всего несколько лет. В 1937 г. из-за убыточно- сти и трудностей в эксплуатации от его использования пришлось отказаться [6].

В годы Великой Отечественной войны в Пензу эвакуировались десятки промышленных предприятий, учреждений, учебных заведений, а вместе с ними и тысячи людей из западных районов страны. Поэтому возникла острая необходимость организовать в городе регулярный общественный транспорт. Вместо трамвая, проекты которого безуспешно рассматривались на протяжении нескольких десятилетий, предпочтение отдали троллейбусу. Такая переориентация объясняется тем, что город обладал особым рельефом, затруднявшим прокладку трамвайной линии, а также дороговизной строительства последней, особенно в тяжёлые годы войны.

Руководство Пензы обратилось к правительству с прошением об организации в городе пассажирского электротранспорта. 6 февраля 1944 г. СНК СССР постановил «приступить в г. Пензе к подготовительным работам по строительству первой очереди троллейбусной линии протяжённостью 7 км с затратами 500 тыс. руб., с привлечением к указанной работе заинтересованных народных комиссариатов» [7, л. 14]. Проектные работы поручили вести организациям «Дортранспроект» и «Дорстрой». Предусматривалось соединить троллейбусным сообщением южную часть г. Пензы с оборонными заводами № 163 и № 740 с северной частью города и заводом № 50.

Изначально планировалось провести все подготовительные работы по строительству троллейбусной линии в 1944 г. До 1 апреля предполагалось закончить проектные работы, а до 1 ноября - завершить асфальтирование дорог и тротуаров по всей трассе [8, с. 2].

К концу войны проект утвердили, а начальником и главным инженером созданного в Пензе управления строительства троллейбуса назначили приглашённого с завода им. Фрунзе инженера-технолога Б.А. Бахирева. Уже в начале 1945 г. силами дорожно-мостового треста начались подготовительные работы по строительству дорог в Пензе для троллейбусной линии [9, с. 71].

В июне 1945 г. планировалось начать асфальтирование дорог на трассе троллейбуса по ул. Московской, начиная с нижней её части. Но на пересечении ул. Кропоткинской и Московской через почву и покрытие проезжей части стала просачиваться вода в двух местах, разрушая тем самым мостовую. Директору водоканала предложили незамедлительно устранить течь водопровода в указанном месте в самые сжатые сроки. При этом одновременно с ремонтом требовалось произвести полную ревизию коммуникаций с целью принятия срочных профилактических мероприятий в слабых местах по всей трассе троллейбуса, чтобы не сорвать работы по устройству дорог на ней [10, л. 96].

По истечении двух месяцев отделу капитального строительства не удалось приступить к асфальтированию дорог из-за того, что водоканал так и не устранил неисправность. В результате, не дожидаясь ликвидации аварии, началось асфальтирование дорог в тех местах, где было возможно [10, л. 98].

В 1945 г. на создание троллейбусной линии в Пензе правительство ассигновало миллион рублей. На эти средства построили асфальтобетонную дорогу от здания облисполкома до вокзала станции Пенза-1 протяжённостью около 3 км, начались работы по возведению 
тяговой подстанции и троллейбусного депо. На эти же деньги необходимо было приобрести контактное оборудование линий и перестроить на троллейбусной трассе осветительную, телеграфную и телефонную сети.

Строительством асфальтобетонной дороги для новой линии троллейбуса занималось главное управление строительства шоссейных дорог (Гушосдор) по отдельному договору. Дорога строилась шириной 6,5 м. Работами по установке и оборудованию тяговой подстанции занималась строительная организация одного из наркоматов. Все остальные виды работ выполняло особое строительно-монтажное управление треста «Коммунстрой» наркомата гражданского строительства [11, с. 4].

В сентябре 1945 г. СНК СССР принял постановление, согласно которому обязывал народные комиссариаты боеприпасов, вооружения, авиационной и бумажной промышленности принять долевое участие в строительстве троллейбуса. Для этого за счёт своих ресурсов они должны были поставить материалы и оборудование Пензенскому Горисполкому. Главным инженером строительства троллейбусной линии назначили А.Г. Пальцева [12, л. 12-13].

Большую помощь в строительстве троллейбуса оказали промышленные предприятия города. Завод им. Фрунзе изготовил всю арматуру для контактной сети, помогал материалами и квалифицированными кадрами специалистов. Предприятия Министерства машиностроения и приборостроения, в частности, трест «Пензамашприборстрой», построили тяговую подстанцию, где вырабатываемый городской ТЭЦ переменный ток напряжением 6 тыс. вольт с помощью ртутных выпрямителей преобразовывался в постоянный ток напряжением в 600 вольт, оборудовали приборами все сооружения городского троллейбуса. В монтаже контактной сети большую помощь оказали также стахановцымонтёры областной конторы «Центроэлектромонтаж» Орлов, Черчилин, Семёнов и другие. Непосредственное участие в строительстве троллейбуса принимал также коллектив работников городского электрохозяйства $[13$, c. 2$]$.

Трест «Дортранспроект» осуществлял проектирование строительства троллейбусной трассы в Пензе. В работах по составлению проекта выделяется 4 стадии: изыскания, проектное задание, технический проект и рабочие чертежи.

В 1946 г. «Дортранспроект» выполнил проектное задание по троллейбусному депо, вагоноремонтной мастерской, контактному оборудованию и высоковольтной линии на сумму 46,9 тыс. руб. [14, л. 54об]. К 1947 г. были выполнены три стадии, и уже завершалась четвёртая - по рабочим чертежам. Управление строительства Пензенского троллейбуса в связи с этим заключило ещё один договор с «Дортранспроектом» на сумму 51,1 тыс. руб. [15, л. 118].

В 1946 г. на строительство троллейбуса министерство коммунального хозяйства ассигновало 600 тыс. руб., министерства сельхозмашиностроения, машиностроения и приборостроения, авиационной промышленности - 2,5 млн. руб. [16, л. 54]. За этот год на эти средства осуществили строительство тяговой подстанции на 75\%, изготовили подвесную арматуру и на протяжении 1 км подвесили контактную сеть. Также подготовлено $5700 \mathrm{~m}^{2}$ дорог по трассе следования троллейбуса для асфальтирования [16, л. 59].
Строительство троллейбусной линии растянулось на несколько лет. Данную ситуацию можно объяснить несколькими причинами.

Во-первых, генеральная смета на строительство троллейбуса была утверждена народным комиссариатом коммунального хозяйства РСФСР 16 октября 1944 г. в ценах 1936 г. Между тем, материалы на строительство троллейбуса поставлялись в ценах текущего года, а цены на арматуру для подвески контактной сети, изготавливаемую заводом им. Фрунзе превышали лимитную стоимость в два-три раза. Общий ценовой разрыв в сравнении со сметной составлял 702 тыс. руб. [17, л. 220].

Во-вторых, бюро экспертизы министерства коммунального хозяйства РСФСР предложило проектным организациям перепроектировать временные сооружения - путепровод и троллейбусное депо - на постоянные, что также вызвало увеличение проектной стоимости строительства троллейбуса.

По этой причине строительство замедлялось. Для его ускорения нужно было изыскивать средства. Одной из таких мер по удешевлению проекта стало исключение из сметы двухэтажного жилого дома и гаража. Таким образом, удалось сэкономить 727 тыс. руб. В связи с этим, в августе 1947 г. определилась окончательная сметная стоимость строительства троллейбусной линии, которая составила 12,34 млн. руб. [18, л. 299].

В связи с тем, что строительство и обустройство троллейбусной трассы затягивалось, исполком горсовета в начале июня 1948 г. поручает председателям райисполкомов организовать проведение общественных работ по этому объекту с широким привлечением горожан [19, л. 34].

2 ноября 1948 г. Пензенский Горисполком выделил для управления троллейбуса собственное помещение по адресу ул. Московская д. 88, ранее занимаемое ремонтной конторой Северного района [20, л. 27].

С комплектованием предприятия подвижным составом дела обстояли несколько хуже, чем со строительством дорог. Так, в 1948 г. в Пензе имелось всего три троллейбуса, а обучение и стажировку в Москве прошли 13 водителей. Подготовка водителей для пензенского троллейбуса началась ещё осенью 1946 г. в г. Москве. Отбор кандидатов осуществлялся на конкурсной основе. 16 сентября 1946 г. группа в количестве 13 человек приступила к учёбе в Московском институте технического обучения. А практику будущие пензенские водители троллейбуса проходили во втором троллейбусном парке Москвы.

В марте 1947 г. водители, получив дипломы на право управления троллейбусом, вернулись в Пензу. По запросу из Пензы для подготовки рабочих по ремонту троллейбусов, налаживанию работы в депо и службе движения прибыл москвич В.В. Ильин. Он занимался службой движения, составлял графики работы троллейбусов, обучал водителей и кондукторов навыкам обслуживания пассажиров. В.В. Ильин работал в должности начальника службы движения в 19481950 гг. [9, с. 72].

Движение первой очереди троллейбуса в Пензе было открыто 4 ноября 1948 г. по маршруту «Пенза-1 Мебельная фабрика» протяжённостью 9,4 км. Троллейбус работал на линии с 6 ч. утра до 1 ч. ночи с перерывом на профилактический осмотр контактной сети с 13 
до 15 часов. Начальника строительства троллейбуса Маркмана городские власти обязали через средства печати и радио оповестить жителей города о правилах пользования троллейбусом, остановках и тарифах за проезд [21, л. 18].

Весьма интересными являлись некоторые правила пользования троллейбусом. Так, вход в троллейбус осуществлялся исключительно через заднюю дверь, а выход через переднюю. Первые шесть мест с левой стороны предназначались для детей, беременных женщин и инвалидов.

За безбилетный проезд пассажир обязан был оплатить, помимо стоимости проезда, штраф в размере 3 руб. Если нарушитель отказывался платить, то штраф взыскивался в принудительном порядке органами милиции, и что примечательно, уже в десятикратном размере. А вот за проезд детей на буферах, подножках и других выступающих частях троллейбусов, привлекались к ответственности их родители [21, л. 19-20].

4 ноября 1948 г. в честь открытия троллейбусного движения в Пензе на Театральной площади состоялся многолюдный митинг, на котором выступил заместитель председателя горисполкома Евстигнеев. После окончания митинга места в первом троллейбусе заняли депутаты городского Совета, стахановцы промышленных предприятий. Евстигнеев перерезал алую ленту, после чего под звуки оркестра и аплодисменты собравшихся людей троллейбусы отправились в свой первый путь [13, с. 2].

К моменту пуска троллейбуса депо не успели достроить: его строительство растянулось на несколько лет. Ещё в декабре 1947 г. водителя троллейбуса И.Н. Шерстнева и главного инженера А.Г. Пальцева отправили на три месяца в командировку в Берлин с целью привезти из Германии с бывшего военного завода Ардельт (местность Эберсвальде) металлопрокат для строительства депо на ул. Суворова. В начале 1948 г. металлоконструкции демонтированного завода погрузили в эшелон и в сопровождении военной охраны доставили в Пензу [9, с. 72]. Началось долгосрочное строительство троллейбусного депо. К концу 1949 г. закончили каменную кладку производственного и административного корпусов, начали осуществлять монтаж металлоконструкций. Из общего объёма капиталовложений на строительство депо в сумме 750 тыс. руб. на декабрь 1949 г. сумели освоить 542 тыс. руб. [21, л. 50 об]. Строительство депо завершилось только в 1950-е гг.

Сразу же после пуска троллейбуса, по инициативе лучшего водителя Ильина, развернулось социалистическое соревнование за бережное отношение к машинам, строгое соблюдение графика движения, предотвращение аварий и опозданий выхода на линию [13, с. 2].

К началу эксплуатации троллейбуса функционировали следующие объекты: тяговая подстанция, контактная сеть 10 км, троллейбусные дороги с асфальтовым покрытием на расстоянии 5 км, а также временный профилакторий с мастерскими и подсобными помещениями [22, л. 187].

Первый месяц на линии курсировало всего 3 троллейбуса, а к концу года их число возросло вдвое (хотя числилось 8 троллейбусов, но на линю выходило только 6). Сразу же после пуска в эксплуатацию, троллейбус стал пользоваться большой популярностью у жителей Пензы. Только в период с 4 по 30 ноября 1948 г. было перевезено 31,3 тыс. пассажиров [21, л. 20,27]. А за 11 месяцев 1949 г. - 4,74 млн. (при плане в 4 млн. человек) [21, л. 49 об].

Ещё до официального открытия троллейбусной линии был сформирован штат работников троллейбусного парка и определены их зарплаты (табл. 1).

Таблица 1 - Штатное расписание троллейбусного хозяйства Пензы на 1948 г. (пусковой период) [23, л. 5]

\begin{tabular}{|c|l|c|c|}
\hline № & \multicolumn{1}{|c|}{ Должность } & $\begin{array}{c}\text { Кол-во } \\
\text { штатных } \\
\text { единиц }\end{array}$ & $\begin{array}{c}\text { Месячный } \\
\text { оклад, } \\
\text { руб. }\end{array}$ \\
\hline 1 & $\begin{array}{l}\text { Начальник отдела } \\
\text { Движения }\end{array}$ & 1 & 900 \\
\hline 2 & $\begin{array}{l}\text { Начальник сетей } \\
\text { и тяговой подстанции }\end{array}$ & 1 & 900 \\
\hline 3 & Электромастер & 16 & 570 \\
\hline 4 & Водитель I класса & 2 & 550 \\
\hline 5 & Водитель ІІ класса & 4 & 500 \\
\hline 6 & Водитель ІІІ класса & 4 & 450 \\
\hline 7 & Кондуктор І класса & 10 & 300 \\
\hline 8 & Кондуктор билетный & 1 & 300 \\
\hline 9 & $\begin{array}{l}\text { Шофёр грузовой } \\
\text { а/машины (аварийной }\end{array}$ & 4 & 450 \\
\hline 10 & Истопник & 4 & 370 \\
\hline 11 & $\begin{array}{l}\text { Мастер по ремонту и } \\
\text { профилактике }\end{array}$ & 1 & 700 \\
\hline 12 & Слесарь & 8 & 420 \\
\hline 13 & Экономист-плановик & 1 & 750 \\
\hline 14 & Кладовщик & 1 & 400 \\
\hline 15 & Техник-конструктор & 1 & 550 \\
\hline 16 & $\begin{array}{l}\text { Мастер по техническому } \\
\text { снабжению }\end{array}$ & 1 & 700 \\
\hline 17 & Ученики & 12 & 210 \\
\hline 18 & Уборщица & 250 \\
\hline
\end{tabular}

Но первая очередь троллейбусной линии не могла удовлетворить потребностей населения, так как связывала только южную часть города с центром и вокзалом. Население крупнейшего района Пензы - Заводского было фактически оторвано от города из-за недостатка транспорта. В этой связи уже летом 1949 г. началось строительство второй очереди троллейбуса, которой предстояло связать Заводской район с центром города. На её создание и дальнейшее обустройство министерство машиностроения и приборостроения выделило 350 тыс. рублей [21, л. 42].

Объём работ предстоял громадный: требовалось замостить и заасфальтировать целый ряд улиц, поставить опорные столбы и протянуть контактную сеть. Главная трудность заключалась в постройке виадука через железнодорожное полотно и сооружение вала на походах к нему: требовалось выгрузить и насыпать свыше 20 тыс. м $^{3}$ земли и уложить $700 \mathrm{~m}^{3}$ камня.

Предстояла тяжёлая работа, которую требовалось выполнить в короткий срок. Успех зависел, в том числе и от усердия рабочих. Самоотверженно трудились на трассе мостовщики Г. Преображенский, В. Новиков, М. Перфилов, А. Ефремов, И. Гудков и Н. Волынский. Они изо дня в день выполняли свои нормы на 170180\%. Особенно усердно трудились слесарь А. Ерофеев, электромонтёр И. Ирышков, бетонщики И. Медянцев и В. Щупов. Отлично работали также скреперисты Фролов, Моисеев и Пруцков. Благодаря их усили- 
ям в короткий срок был воздвигнут вал на подходах к виадуку [24, с. 2].

Строительство шло не без трудностей. Большая часть автотранспорта города была занята на вывозке хлеба в районах области, поэтому Горисполком решил привлечь для работ по отсыпке грунта на трассе троллейбуса гужевой транспорт предприятий, учреждений и организаций города и обязал председателей райисполкомов установить повседневный контроль за выполнением задания [25, л. 276].

На помощь строителям второй очереди троллейбуса пришла также и общественность Пензы. Только население Заводского района отработало на стройке 5 тыс. человеко-дней. В подвозке и вывозке грунта, перевозках камня участвовали десятки автомашин. Активное участие в строительстве принимали коллективы велозавода, часового завода САМ и других предприятий Заводского района. В ночь с 3 на 4 ноября работы закончились, и по новой трассе был совершён первый пробный рейс, который показал, что всё сделано добротно и линия готова к эксплуатации [24, с. 2].

5 ноября 1949 г. в 12 часов дня по случаю сдачи в эксплуатацию второй очереди троллейбусной линии состоялся праздничный митинг. Городская пресса широко освещала данное событие. «У только что отстроенного железнодорожного виадука собралось большое количество людей. Они с нетерпением ожидают появление первого троллейбуса. И вот на широкой и гладкой мостовой показывается сверкающая на солнце машина.

Председатель горисполкома Рябов объявляет митинг, посвящённый пуску второй очереди троллейбусной трассы, открытым. Торжественно звучит Государственный Гимн Союза ССР. Слово предоставляется секретарю Пензенского Обкома и горкома ВКП (б) И.К. Лебедеву. Он обращает внимание на то, что строительство второй очереди троллейбуса было проведено в 10 раз быстрее, чем строительство первой очереди.

В заключение своей речи Лебедев поздравил трудящихся Заводского района с замечательным праздничным подарком - открытием троллейбусного движения и торжественно перерезал красную ленту. Водитель И. Шерстнев включает мотор, и первый троллейбус идёт в путь по новой трассе» [26, с. 4].

С большим воодушевлением восприняли жители Заводского района открытие новой троллейбусной линии. «Радости-то какой дождались, сказала контролер велозавода Ревунова, двадцать лет проработавшая на этом предприятии. - Спасибо товарищу Сталину за подарок». [27, с. 2]

В связи с окончанием строительства второй линии троллейбуса, началось движение по маршруту «Мебельная фабрика - завод САМ». С увеличением троллейбусов и протяжённости трассы был утверждён дополнительный штат эксплуатационного персонала на ноябрь-декабрь 1949 г. в количестве 21 единицы с фондом зарплаты 25,1 тыс. руб. [28, л. 119].

За 1949 г. троллейбусы г. Пензы проехали 396 тыс. км и перевезли 5,41 млн. пассажиров. Благодаря вводу в эксплуатацию в ноябре 1949 г. второй очереди троллейбуса и росту протяжённости линии с 9,4 км до 13,4 км пассажирский пробег за 1950 г. увеличился более чем в два раза и составил 846 тыс. км. За этот же год пензенский троллейбус перевёз 10,88 млн. чел. [9, с. 73].

В 1950 г. в работе троллейбуса проявляются недостатки. Основным из них стало низкое качество про- филактического ремонта парка, следствием чего за 5 месяцев 1950 г. имели место 63 возврата машин с линии по причине технической неисправности. В целях улучшения организации профилактического ремонта машин, укомплектовали ремонтную группу из квалифицированных рабочих на сдельной оплате. Весь подвижной состав закрепили за водительским и кондукторским составом [29, л. 97].

Различные недостатки наблюдались и в работе троллейбусной линии. Данные ситуации довольно широко освещались в местной прессе. «Остановка троллейбуса - облдрамтеатр. Собрались десятки пассажиров. Сверкая огнями, плавно подходит троллейбус.

- Пустой! Полон! - раздаются противоречивые реплики.

Кто-то вслух подсчитывает количество сошедших с передней площадки людей: один, два, пять, семь, десять... Сейчас все сядем!

Открывается дверь. Пропустив трёх-четырёх человек, кондуктор объявляет: - Осторожно! Машина трогается! И, действительно, полупустой троллейбус отходит. В образовавшейся сутолоке кто-то упал, кому-то отдавили ногу.

- Опаздывают, а теперь вот за счёт сокращения остановок и нагоняют! - сердито говорит кто-то из пострадавших». [30, с. 3]

Этот и подобные сигналы обсуждались на рабочих собраниях, а иногда администрация, для повышения качества работы, прибегала к различным санкциям, в частности, выговорам и штрафам.

Bblводы исследования. Следует отметить, что предпочтение было отдано троллейбусу, а не трамваю по той причине, что территория города отличается особым рельефом. Благодаря троллейбусу, в Пензе построили асфальтовый завод и заасфальтировали дороги, без которых его эксплуатация была бы невозможной.

Создание троллейбусной линии велось в течение нескольких лет. Начавшись ещё в годы Великой Отечественной войны, строительство первой троллейбусной линии закончили к ноябрю 1948 г. Столь долгий срок работ объясняется тем, что было необходимо провести достаточное количество подготовительных работ, связанных порой, с созданием дорог с опорными столбами и освещением практически на пустом месте. Зато уже через год после ввода в эксплуатацию первой очереди троллейбуса, была сдана вторая, связавшая центр города с Заводским районом. Троллейбусные линии привели к увеличению мобильности горожан, а также способствовали хозяйственному развитию, расширению и освоению города. Пенза встала в один ряд с крупными городами, подчеркнув тем самым, свой статус областного центра.

\section{СПИСОК ЛИТЕРАТУРЫ:}

1. Петров С.П. Пенза: краткий исторический очерк / под ред. М.В. Савина. Пенза: Кн. Изд-во, 1955. 206 с.

2. Путь в полвека: Пензенская область за 50 лет Советской власти. Саратов-Пенза: Приволж. кн. изд-во, 1967. $367 \mathrm{c}$.

3. Полосин Н.И. История пензенского троллейбуса // Краеведение. 1998. № 3-4. С. 71-75.

4. Кашаев П.В. Пенза: от пролетки до троллейбуса // Городское пространство в исторической. ретроспективе: Материалы Всероссийской научно-практической конференции, посвященной 350-летию основания го- 
рода Пензы / Под общ. ред. О.А. Суховой. Пенза: ГУМНИЦ ПГУ, 2013. 200 с.

5. Кашаев П.В. Из истории возникновения общественного транспорта Пензы // Наша Пенза. 2003. 1723 октября.

6. Ахромеев Д. Пензенскому трамваю - 70 лет! // Молодой ленинец. 2005. - 25 января.

7. Государственный архив Российской Федерации (далее - ГАРФ). Ф. Р-5446. Оп. 1. Д. 224.

8. Сталинское знамя. 1944. - 26 февраля.

9. Полосин Н.И. История пензенского троллейбуса // Краеведение. 1998. № 3-4. С. 71-75.

10. Государственный архив Пензенской области (далее-ГАПО). Ф. Р-847. Оп. 1. Д. 1352.

11. Сталинское знамя. 1945. - 19 августа.

12. ГАПО. Ф. Р-453. ОП. 1а. Д. 214.

13. Сталинское Знамя. 1948. 5 ноября.

14. Филиал РГАНТД. Ф. Р-852. Оп. 2-6. Д. 10.
15. Филиал РГАНТД. Ф. Р-852. Оп. 2-6. Д. 12.

16. Отдел фондов общественно-политических организаций ГАПО. Ф. п-37. ОП. 1. Д. 1060.

17. ГАРФ. Ф. А-314. ОП. 2. Д. 27.

18. ГАРФ. Ф. А-314. Оп. 2. Д. 1207.

19. ГАПО. Ф. Р-2531. ОП. 1. Д. 9.

20. ГАПО. Ф. Р. 453. ОП. 1а. Д. 222.

21. ГАПО. Ф. Р-453. ОП. 1а. Д. 214.

22. ГАРФ. Ф. А-314. Оп. 22. Д. 3309.

23. Государственный архив Пензенской области (ГАПО). Ф. Р-453. ОП. 1а. Д. 221.

24. Сталинское Знамя. 1949. - 7 ноября.

25. ГАПО. Ф. Р-453. ОП. 1а. Д. 230.

26. Молодой Ленинец. 1949. - 7 ноября.

27. Сталинское Знамя. 1949. - 7 ноября.

28. ГАПО. Ф. Р-453. ОП. 1а. Д. 232.

29. ГАПО. Ф. Р-2038. ОП. 1. Д. 1676.

30. Сталинское знамя. 1950. - 31 января.

\title{
ON THE HISTORY OF THE TROLLEYBUS IN PENZA
}

(C) 2016

\author{
A.V. Gorshenin, assistant of the Chair of Humanitarian Disciplines \\ Medical University «Reaviz», Samara (Russia)
}

\begin{abstract}
Urban transport is an integral part of the urban economy. Without public transport it is impossible to imagine the existence of large and medium-sized towns. The analysis in this paper discusses the history of the formation of trolleybus transport in Penza in the 1940s. In pre-revolutionary years local governors wanted to organize work of the tram in Penza, but all ideas remained unrealized. After the October revolution and the beginning of industrialization, city authorities faced the task of the organization of regular intercity transport again. In the 1930s at the request of workers in Penza the narrow-gage city train traffic was organized. But it did not operate long: 2 years later owing to the technical difficulties, it wascancelled. In the years of the Great Patriotic War, in connection with the growth of the city, a need arose regular work of passenger transport. It was decided to build a trolleybus line. The main sources of the research are based on the documents of the Federal and regional archives. They are the State archive of the Russian Federation, the Penza branch of the Russian state archive of scientific-technical documentation, the State archive of the Penza region and the Department of public funds-political organizations GAPO. The archival layer of source materials of local periodicals of the considered years complements this database. Complement the archival layer of source materials is supplemented by local periodicals of the historic period in question. The paper focuses on such processes as design, construction and first few years of operation of the trolleybus in Penza. It includes problems that arose during the construction of the trolleybus route and analyses its role in the economy of Penza.

Keywords: regional history, history of everyday life, city, trolleybus, tram, urban transport, public transport, communal economy, municipal economy, improvement, town planning, Great Patriotic War, post-war period, Penza region, Penza.
\end{abstract}

\section{ЭРОЗИЯ ТРУДОВОЙ ЭТИКИ СОВЕТСКОГО КРЕСТЬЯНСТВА В ПОСЛЕВОЕННОЕ ДЕСЯТИЛЕТИЕ (НА МАТЕРИАЛАХ УЛЬЯНОВСКОЙ ОБЛАСТИ)} (C) 2016

О.Р. Хасянов, кандидат исторических наук, заведующий кафедрой философии и истории

Ульяновская государственная сельскохозяйственная академия имени П.А. Столыпина, Ульяновск (Россия)

Л.Н. Галимова, доктор исторических наук, профессор кафедры гуманитарных и социальных дисциплин Ульяновский институт гражданской авиаџии имени главного маршала авиаџии Б.П. Бугаева, Ульяновск (Россия)

Аннотация. Современные проблемы в аграрной сфере объясняются тем, что в течение десятилетий для государственной аграрной политики было характерным пренебрежение интересов основного производителя деревни, внеэкономическое принуждение к труду, отчуждение от земли и произведенной продукции. Ущемление социальных прав крестьянства неизбежно приводило к урбанизации, миграции населения из деревень.

В статье на основе анализа современной научной литературы и архивных документов, которые впервые вводятся в научный оборот, исследуется сложный процесс разрушения ценностного отношения колхозного крестьянства к труду в общественном хозяйстве. По мнению авторов, материальные трудности сельского общества в военные годы привели к восстановлению в сельском обществе прежних форм хозяйственной деятельности, а именно: единоличной работы на своем земельном участке. Победное завершение войны привело к восстановлению довоенной государственной политики в области сельского хозяйства, но крестьяне продолжали игнорировать общественную работу. Авторы полагают, что государственные кампании, направленные на восстановление 